\title{
The morphology and development of Kalahroud Cave, Iran
} \author{
and Karine Wainer ${ }^{4}$ \\ ${ }^{1}$ Department of Geology, Isfahan (Khorasgan) Branch, Islamic Azad University, Isfahan, Iran \\ ${ }^{2}$ Department of Geology, University of Isfahan, Isfahan, Iran \\ ${ }^{3}$ School of Geography and Earth Sciences, McMaster University, Canada \\ ${ }^{4}$ Department of Earth Sciences, Oxford University, England
}

Shirin Bahadorinia ${ }^{1 *}$, Sayed Hassen Hejazi ${ }^{1}$, Alireza Nadimi ${ }^{2}$, Derek C. Ford ${ }^{3}$,

\begin{abstract}
Kalahroud Cave is located in central Iran, $\sim 50 \mathrm{~km}$ north of Isfahan. The landscape is a typical mountain desert morphology of cuestas dissected by ravines and gorges created during rare surface run-off events; crest lines are $\sim 2800 \mathrm{~m}$ asl and lowlands at $\sim 2100 \mathrm{~m}$ asl. Kalahroud Cave (4500 $\mathrm{m}$ of mapped passages, $\sim 60 \mathrm{~m}$ deep) is entered through breakdown in the eastern wall of a gorge. The host rock is a Cretaceous limestone and mudstone formation $60 \mathrm{~m}$ in thickness, underlain by sandstones and conglomerates and overlain by weakly permeable calcareous marl strata, all dipping $15-20^{\circ}$. Below the entrance breakdown, two corrosion notch chambers give access to a rectilinear, quasi-horizontal maze of joint-guided passages extending $\sim 500$ m eastwards. Rock solution morphology created by slowly flowing phreatic waters predominates (solution pockets, partitions, paragenetic forms, etc). Seven shafts are known that discharged water into the maze and chambers from inaccessible passages below. From XRD analysis, the paragenetic sediments derive from the mudstone interbeds. There are small displays of frostwork, helictites and thin flowstones typical of vadose speleothem deposition in arid caves. Below the level of the corrosion notch, more complex sub-aqueous and shelfstone calcites are overlain by accumulations of calcite rafts up to $70 \mathrm{~cm}$ in depth. Raft deposition continues today. It is proposed that the cave is of hypogene origin, serving to discharge interformational groundwaters into the gorge, and becoming de-watered as the latter was deepened. The corrosion notches are due to cessation of deepening. From $U$ series dating, the modern phase of raft deposition began about 10,000 years ago. The sequence and ages of older events will be investigated in future work.
\end{abstract}

Keywords: rectilinear maze, corrosion notch rooms, hypogene cave, calcite rafts, arid climate, Iran Received 12 June 2016; Revised 27 September 2016; Accepted 27 September 2016

Citation: Bahadorinia S., Hejazi S.H., Nadimi A., Ford D.C. and Wainer K., 2016. The morphology and development of Kalahroud Cave, Iran. International Journal of Speleology, 45 (3), 243-257. Tampa, FL (USA) ISSN 0392-6672 http://dx.doi.org/10.5038/1827-806X.45.3.2008

\section{INTRODUCTION}

Iran is a large and mountainous country, tectonically a part of the active Alpine-Himalayan orogenic belt. The full range of the standard soluble rocks (the carbonates and evaporates) is to found in the area. Outcrops of salt in the Hormoz region (the southern Zagros Mountains) are especially well-known because of the occurrence of namakiers (glaciers of salt being extruded from diapirs) there (Jennings, 1985). However, carbonate rocks are predominant in outcrop, covering about $185,000 \mathrm{~km}^{2}$ or approximately $11 \%$ of Iran's land area (Raeisi \& Laumanns, 2003). Most of their occurrences display some karst landforms and they are of significant importance for water supply in many regions because of the aridity of much of the country. In spite of this large extent, the number and lengths of known caves are less than might be expected. There are many highland karst aquifers without any discovered cave systems at present, although big springs emerge at their base levels of erosion. Multiple levels of cave development are to be expected as results of the rapid rates of tectonic uplift and the high local relief. The intensely deformed (folded and faulted) geologic structures and the limits placed by aridity on development of mature karst aquifers are probably the major reasons for the small number of known caves and their minor lengths.

Organized amateur caving began in 1945 (Javanshad, 1995). British cavers discovered and explored a major vadose shaft and drain cave, Ghar Parau, in the central mountains in the 1960s (Judson, 1973); it was the deepest known Iranian cave for many years but recently has been surpassed by Jojar 
Cave at $-806 \mathrm{~m}$. Czech cavers and the Geological Survey of Iran organized more systematic surveying campaigns in the 1990s and early years of the present century, focusing on the Hormoz region where they discovered remarkably long caves in salt; one of them, Tri Nahacu, is currently the longest salt cave known anywhere at 6,580 m (Bosák et al. 1999; Bruthans et al., 2006a,b). Subsequently, there have been speleological training expeditions organized by some of the leading Iranian mountaineering clubs, and the Union Internationale de Spéléologie (UIS) has helped to overcome the lack of international contacts for the Iranian caving community (ISEI, 2008). The first "Iran Cave Directory" in English, published by Raeisi \& Laumanns (2003), provided details on some 550 caves. A $3^{\text {rd }}$ edition increased this to more than 2000 caves (Raeisi et al., 2012). In 2011 an Iranian Cavers and Speleologists Association (ICSA) was founded and currently has more than one hundred members from all over the nation.

In addition to cave exploration, speleological studies are also being undertaken in a few Iranian caves. Hydrogeological investigations in Shapour Cave showed that the Shapour River was the principal source of water creating the cave but that, in addition, meteoric seepage waters from a much broader catchment area made important contributions to the development of a large regional system. What we see as Shapour Cave today is the relict of a once much greater cave that has been destroyed by surficial erosion over time (Raeisi \& Kowsar, 1997). Rezaei and Nakhaei (2008) studied the genesis of Kattale Khour Cave, showing that this large cave with its anastomosing passages was formed by flood waters and allogenic recharge; the water table shifted position, inducing cave formation at three different levels. There is no direct evidence of any hypogene activity, but further studies are warranted at this cave. Research at Khasse Tarash Cave (Sabokkhiz et al., 2012) focussed on the geotourism analysis and mineralogy of the speleothems. They did not made detailed cave genesis and morphology in this case. Hejazi et al. (2015) studied Yekke Chah Cave, a small cave located in Golpayehan, Isfahan province, and proposed a hypogene origin. "An Introduction to Kalahroud Cave, north of Isfahan, Iran" (Bahadorinia, 2013) was a study undertaken as an MSc degree project by the first author of this paper that reported on initial sedimentary, speleological and morphological investigations carried out during several visits to the cave; the paper presented here includes its findings and expands upon them.

\section{THE SETTING OF KALAHROUD CAVE}

Kalahroud Cave is located at Lat. $33^{\circ} 22^{\prime} 21^{\prime \prime}$ N, Long. $51^{\circ} 34^{\prime} 35^{\prime \prime} \mathrm{W}$, in the Karkas and Kohroud River Basin in the mountains of the Central Iran tectonic zone, approximately $300 \mathrm{~km}$ south of Tehran and $50 \mathrm{~km}$ north of Isfahan (Fig. 1a). The regional landscape is typical of warm to hot desert mountain morphology, being dominated by steep ravines and gorges created by stream dissection of the massifs, with detrital fans and alluvial flats around their margins, all created during the rare (a-periodic) surface flood events. The Basin crest lines are between 2800 and $2900 \mathrm{~m}$ asl and the outlets into surrounding lowlands are at $\sim 2100 \mathrm{~m}$ asl.

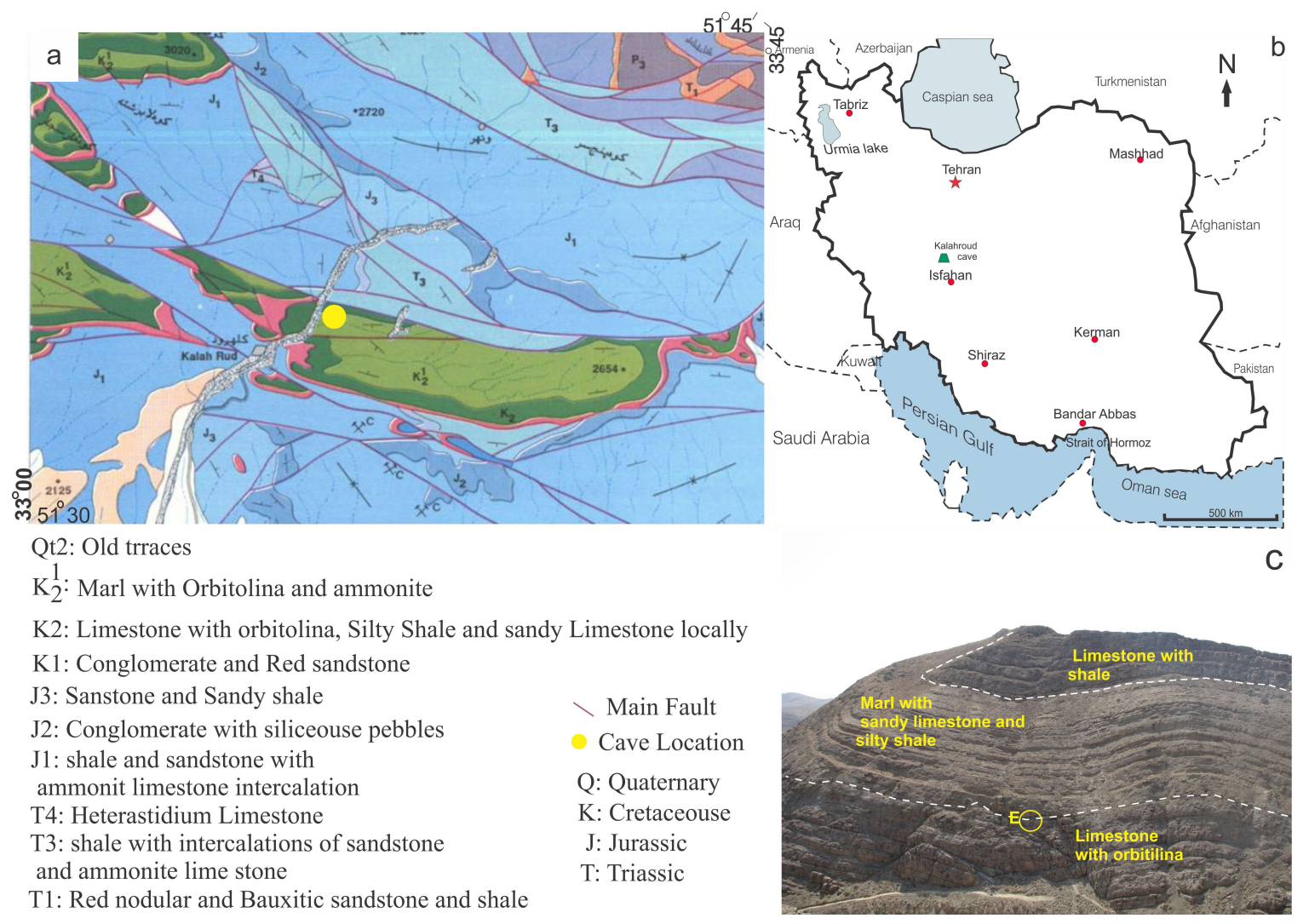

Fig. 1. a) Geological map of the locality around Kalahroud Cave, with the cave indicated (yellow dot); b) Location of Kalahroud Cave in Iran; c) Google Earth oblique image showing the bedrock formations. The cave entrance is marked with a circle. 
The region is semi-arid to arid, with $163.7 \mathrm{~mm}$ average annual precipitation and a mean temperature of $22.1^{\circ} \mathrm{C}$ being measured at the village of Kalahroud, one $\mathrm{km}$ downstream of the cave (Fig. 2). The 'wet season' there extends from November to April, but only one substantial flood event has been reported during the past twenty years. It destroyed a shrine building located in the river bed just below the cave entrance. The floods come from the local ranges and the greater Karkas highlands to the north. There is little vegetation except around artificial oases maintained by groundwater. Farms and small villages obtain their water from historic systems of 'qanats', drainage capture tunnels dug long and deep into the alluvial fans and other deposits.

The local geology (Zahedi, 2005) is shown in Figs. 1b-c, 2 , and 3 . The bedrocks are a regularly bedded, mixed clastic-carbonate sedimentary sequence aggregating $180 \mathrm{~m}$ in thickness. At the base are sandstone and shale with Ammonitic limestone intercalations (unnamed formation, Late Jurassic,), overlain by $80 \mathrm{~m}$ of conglomerate and red sandstone (Sangestan Formation, Early Cretaceous). Above this, the rock that hosts the cave is a thick to massively bedded Orbitolina limestone with lesser, thinner beds of arenaceous limestone and silty shale (Taft Formation, Aptian) aggregating $\sim 40 \mathrm{~m}$ in thickness. This is overlain by $50 \mathrm{~m}$ of thinner-bedded, marly limestones with Orbitolina and Ammonitica, that function as a weakly permeable caprock. On top are a final $\sim 10 \mathrm{~m}$ of stronger limestones with minor shale and marl (Late Cretaceous; see Fig. 1b).

Structurally this area is located on the southwestern margin of the Urumieh - Dokhtar Magmatic Belt of the Central Iran tectonic zone (Berberian et al., 1982). Early movements on Kalahroud Fault, a major fault to the north of the cave, flexed and folded the local strata to create an anticlinal structure. As Figs. 2 and 3 show, fluvial dissection has entrenched deeply into its core and the cave is developed in a shallow cuesta that survives on the southern flank. The dip of the beds is generally $15-25^{\circ}$ to the southeast in the vicinity of the cave entrance but becomes locally shallower in angle to the east. There are two principal joint sets, centered on bearings of 355 and $88^{\circ}$, which control the orientation of the northward- and eastwardtrending cave passages respectively. Some joints are vertical, while others are normal to the dipping beds. A local, low-angle thrust fault from the southeast is important in the entrance section of the cave (Fig. 3a).

The crest of the Kalahroud cuesta is $\sim 2400 \mathrm{~m}$ above sea level. A torrential, a-periodic stream, 'Kalahroud River', has entrenched a shallow gorge across it (Fig. 2). It is now aggraded, with a floor of sand and gravels at $\sim 2295 \mathrm{~m}$ asl that is known to be about $10 \mathrm{~m}$ deep and burying a bedrock channel floor beneath it. There is one alluvial terrace five meters above the modern dry channel. The cave entrance is in cliffs at $2323 \mathrm{~m}$ asl, $28 \mathrm{~m}$ above the dry valley floor. Local people report that there is one small perennial seep or spring at $\sim 2310 \mathrm{~m}$ asl in the foot of cliffs north of the cave (Fig. 3a; Point a) and one occasional spring at $2303 \mathrm{~m}$ further down the valley (Fig. 3a, Point b).

\section{THE MORPHOLOGY AND DEPOSITS OF THE CAVE}

\section{Morphologic overview}

Kalahroud Cave has a surveyed length of $4503 \mathrm{~m}$ of explored passages (Figs. 3 and 4). There are three morphologically distinct parts:- (i) from the entrance (Fig. 5a) a steep breakdown passage or ramp extends broadly down the thrust fault to a depth of $\sim 45 \mathrm{~m}$. There the form changes to (ii) two large horizontal solution notch chambers beveling the dipping strata, with multiple notches, solution pockets and pendants, tapering ramiform extensions upwards and laterally, and blind pits (shafts) in the floors. Two constricted tributaries enter at the notching level to give explorers access to (iii) The Maze, which is a joint-guided rectilinear maze with irregular, predominantly phreatic, form. There have been periodic pools many meters in diameter in the two large chambers, indicated by stranded calcite raft debris and many tower cones built up to precise paleo-water surfaces.

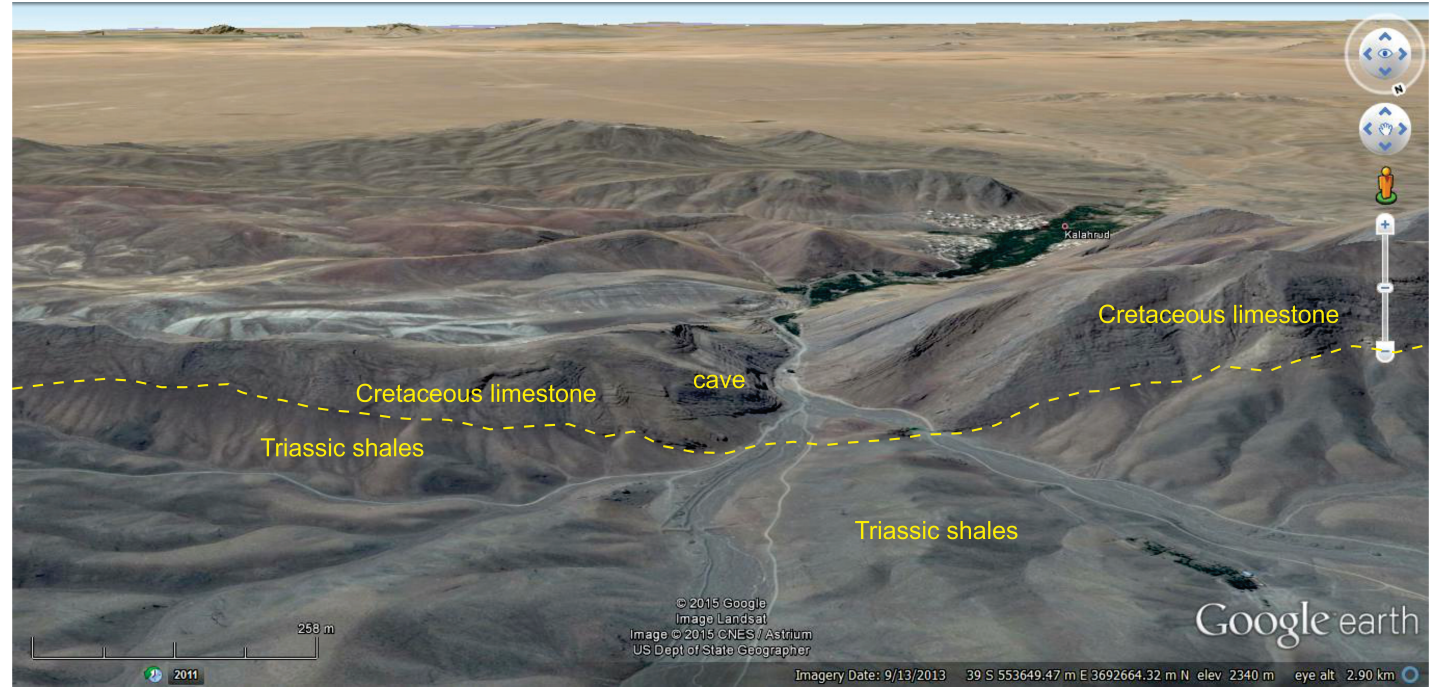

Fig. 2. Google Earth oblique image of the local area, looking south. The cave entrance is located in the eastern wall of a gorge cut through a limestone cuesta by an a-periodic desert stream, 'Kalahroud River'. The village of Kalahroud, in a qanat-supported oasis is seen downstream. 

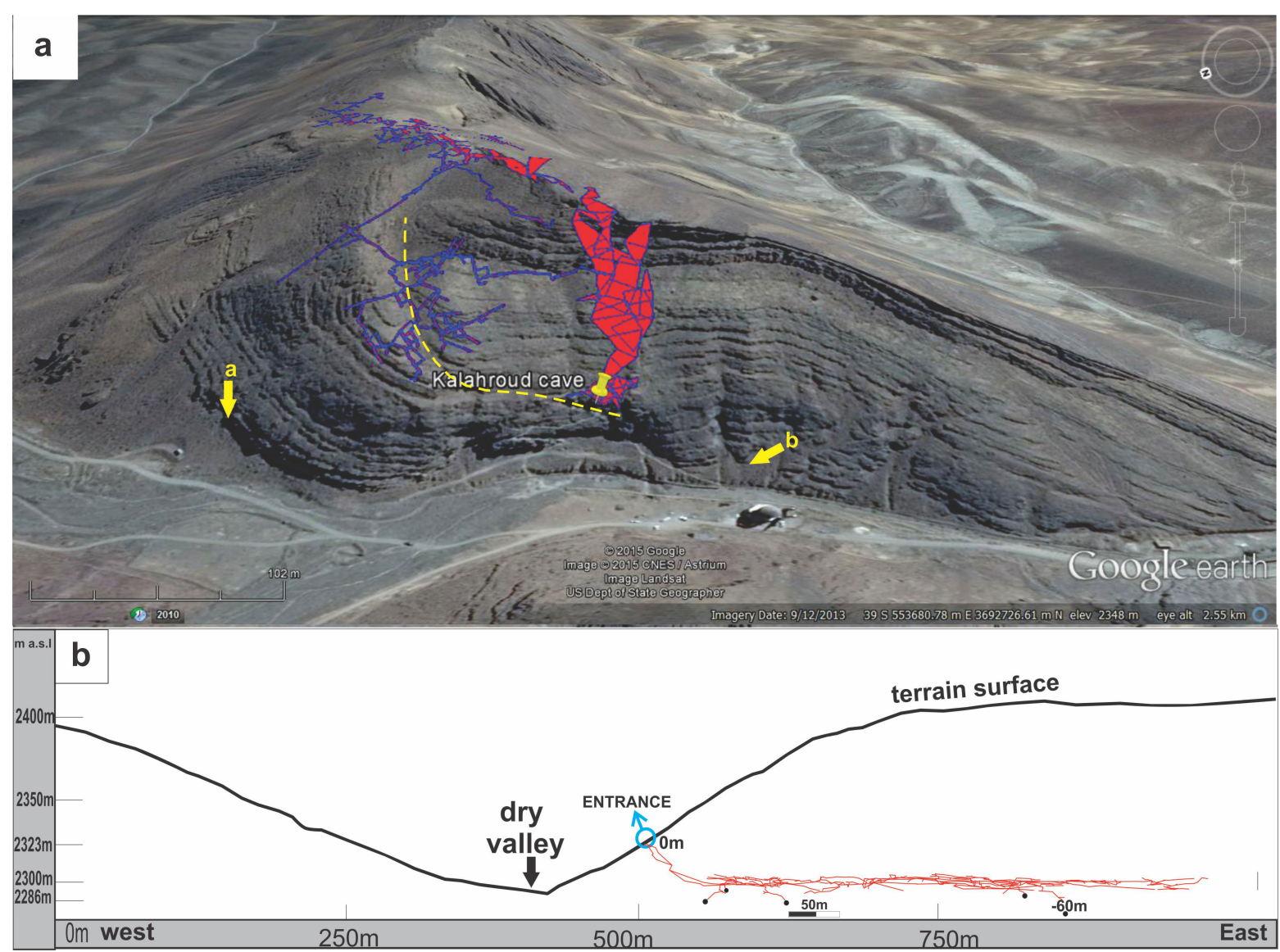

Fig. 3. a) Google Earth oblique image looking east along the cuesta, with an oriented image of the Kalahroud Cave map superimposed on it. The dry channel of Kalahroud River is seen clearly. Points $a$ and $b$ indicate a perennial and an occasional spring. The trend of the thrust fault at the cave entrance is marked by the dashed yellow line; b) The long section of the cave. Black dots show the bottoms of some of the shafts.

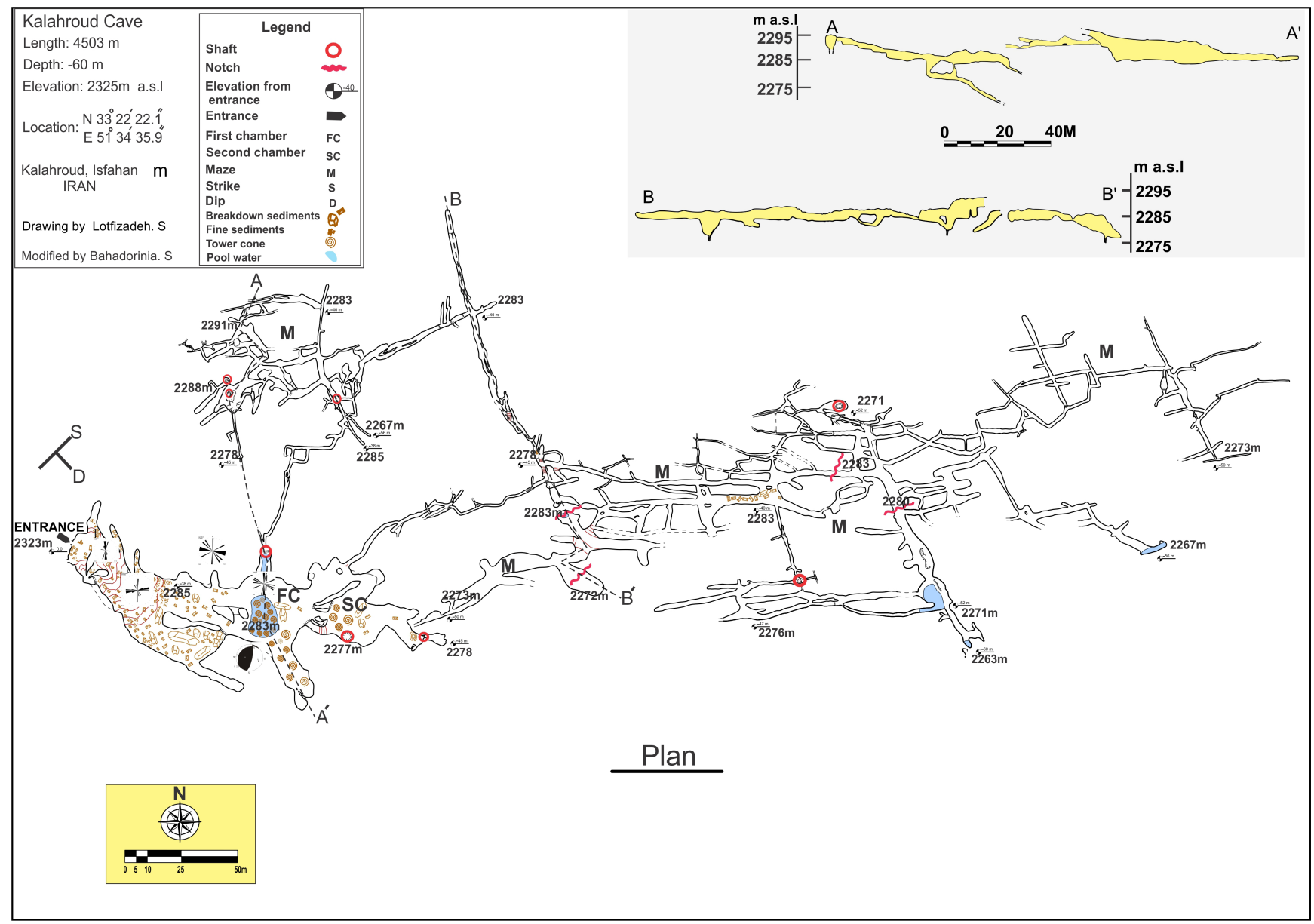

Fig. 4. Plan of Kalahroud Cave with spot elevations in meters. Locations of phreatic lifting shafts and waterline corrosion notches in The Maze are also shown. A-A' and B-B' are projected sections across the east-west trend of the cave. 


\section{The Entrance Ramp}

No evidence of a solutional origin is preserved in the entrance breakdown passage, as Fig. 5 shows clearly. The breakdown blocks are large, the biggest being $>100 \mathrm{~m}^{3}$ in volume and incorporating multiple beds of the limestone. Separation occurred along joints, thrust faults (Fig. 5c, d) and a few of the bedding planes. This collapse can be attributed to solutional undermining of the rock below the thrust fault. The consequent fracturing extends above it, including some further local falls. Significant amounts of finergrained detritus with angular shards can be seen in places: studies show that they are colluvium intruding from the overlying hill slopes via the fracturing.

\section{The Maze}

The joint-directed maze of solutional passages beyond the notch chambers is the predominant component of the cave (Figs. 3, 4). The topographic long section in Fig. $3 \mathrm{~b}$ shows that the accessible passages in this maze are tightly confined to a zone little more than $30 \mathrm{~m}$ in height. The highest ceilings rise only to $\sim 2295 \mathrm{~m}$ asl, although the host Orbitolina limestone (Taft Fm) extends up to $50 \mathrm{~m}$ higher than this along the northwest side of the cuesta. The lowest known point is at $2263 \mathrm{~m}$ asl. There is accessible multi-storey development (upper and lower levels as much as $18 \mathrm{~m}$ apart) in several parts of the maze. Although appearing to be nearly horizontal when projected in long section (Fig. 3b), The Maze is tilted very gently southwards down the stratal dip. It is important to note that all of the passages are located within roughly the mid-section of the $40+m$ of the Taft Fm. The explored maze appears not to be confined in any manner by the overlying and underlying, less permeable and soluble strata, which is in strong contrast to the situation in many other joint maze caves described in the literature.

The bedrock morphology of the maze is dominated by solution forms (speleogens) that are particularly associated with dissolution in phreatic waters that were flowing slowly (e.g., Klimchouk, 2000; Ford \& Williams, 2007; Bella \& Bosak, 2012; Audra \& Palmer, 2015). Figure 6 shows examples of the most common cross-sectional form, a passage initiated along the junction of a joint with a bedding plane that was then enlarged primarily upwards and downwards in the joint. The amount of enlargement up or down (e.g., the height of the ceiling) can vary irregularly along a particular joint, as seen in Fig. $6 a$ and b, or it may maintain a more steady height until the water flow switched to a different bed (Fig. 6c, d).

Figure 7 shows examples of the 'partitions' and 'windows' that have developed in some of the larger joint passages, or in small rooms formed at their junctions. "Partitions are thin separations between adjacent passages that may be in the local bedrock or formed by various kinds of planar resistant structures exhumed by dissolution, such as the lithified fill of fractures or faults and paleokarstic bodies. Sometimes they are only a few centimeters thick so that a "window" can be created by a punch with the hand. They attest to origin by slow, selective solution of the rock" (Klimchouk, 2007).
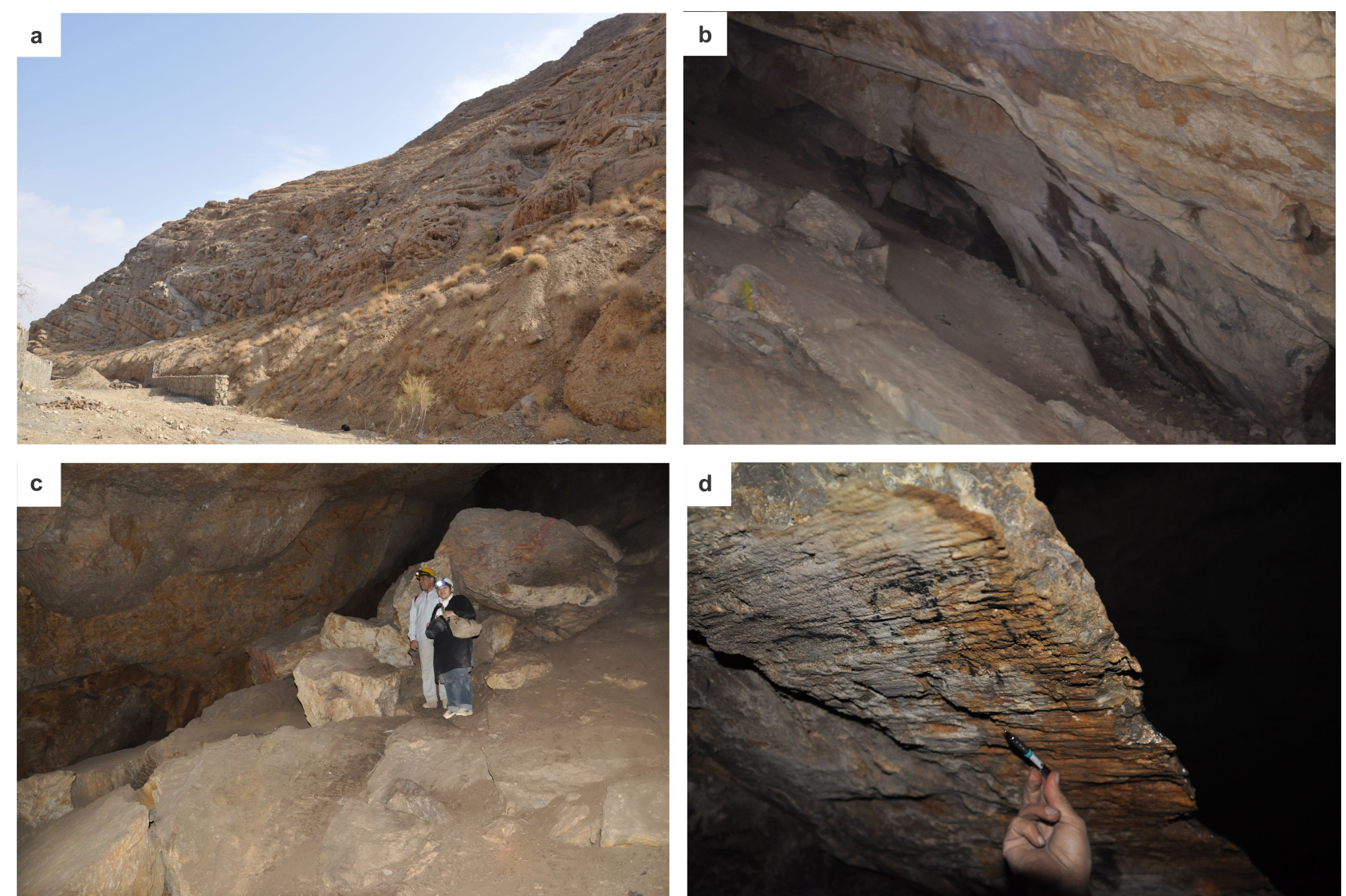

Fig. 5. a) The Kalahroud River Gorge, with the stony path up to the cave entrance seen in the background left. An alluvial terrace 3-4 m above the modern dry river bed probably reflects a recent tectonic movement; b, c) Photos illustrating the very large block breakdown along a thrust fault that created the Entrance Ramp section of the cave; d) A close up view of one of the many slickenside surfaces seen in the Ramp. 

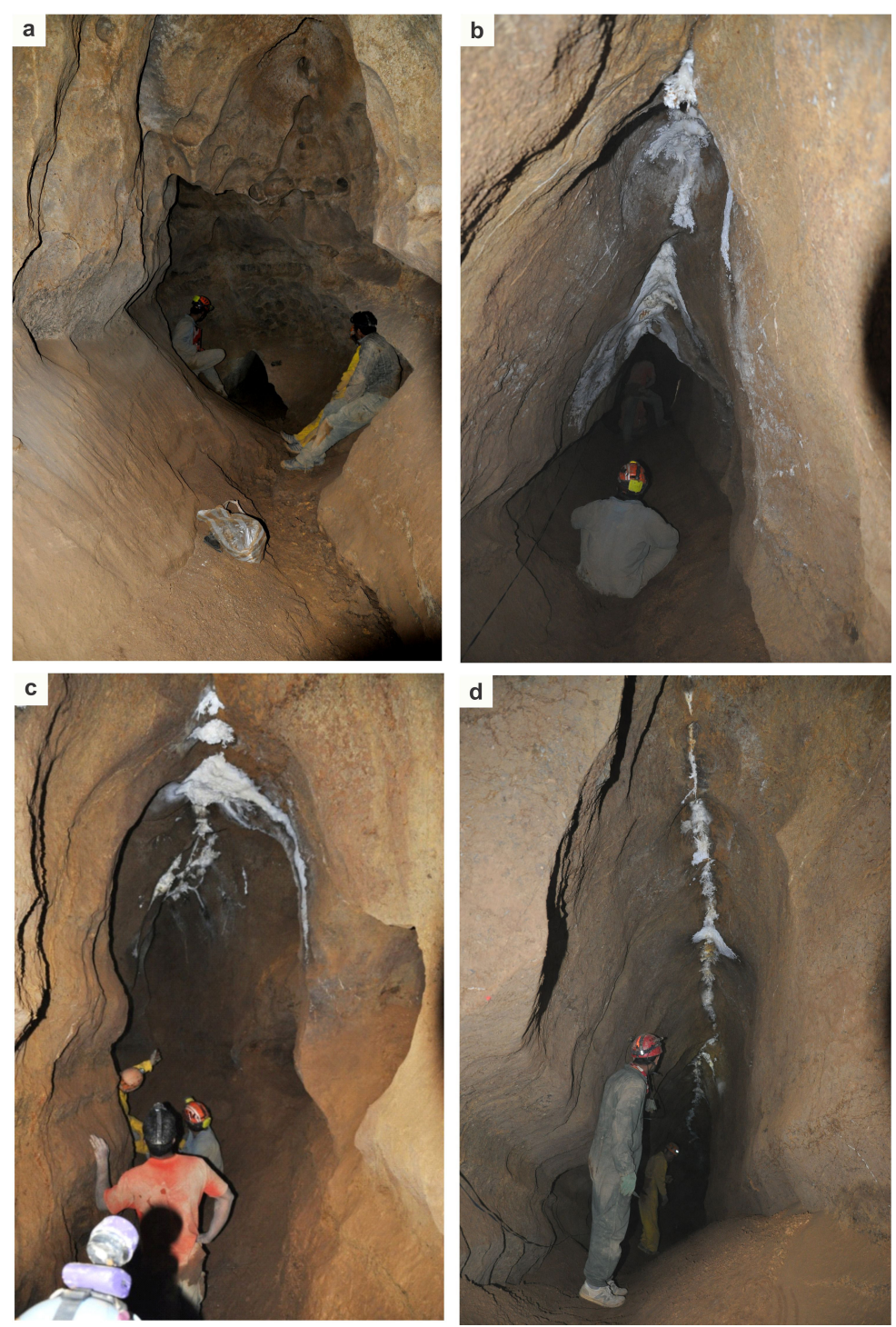

Fig. 6. Four examples of typical passage cross-sections in The Maze to show the dominance of joint control of the solution morphology. White precipitates in the roof joints are precipitated calcite and aragonite (confirmed by XRD analyses).

There are many joint-controlled solution pockets extending upwards above general ceiling levels in the passages. The majority are sharply tapered (Fig. 8a), rather than having a broadly rounded 'cupola' form like many of the pockets described in recent literature on caves considered to be of hypogene origin (e.g., Calaforra \& de Waele, 2011; Temovski et al., 2013). Other pockets are shafts of more uniform diameter; the example shown in Fig 8b is discharging seepage that has passed through the marly cover strata, and is now depositing calcite and aragonite speleothems.

Seven well-developed sub-circular downwards shafts are known in the explored cave (see Figs. 4 and 3b). Others may be buried by the abundant deposits of silt and clay found everywhere in The Maze, while some more elongated forms may not have been recognized as such. The known shafts are 5-8 m deep, mostly too narrow to explore but apparently floored in mud or calcite raft fillings. One larger shaft in the Second Chamber (Fig. 8d) has always had standing water at the bottom when observed. In all cases it appears that the shafts served to channel flow upwards from below ('phreatic lifts') rather than being shafts of vadose origin draining downwards. The two examples shown in Figure 8c, d are typical of the circular form.
Calcite rafts and other deposits seen in Fig. 8d are considered later.

'Paragenesis' occurs when a filling of insoluble silt or clay, settled from flowing water, builds upwards in volume to protect the cave floor and so direct any further solution of the bedrock upwards into the ceiling, or laterally into the walls if the stream is at the water table (Pasini, 1973, 2012; Renault, 1968; Ford \& Williams, 2007). Such fillings are abundant in The Maze, where they have helped to create rounded arch forms or lateral widening and undercuts. Four examples are shown in Fig. 9; in viewing them it should be understood that the fillings seen today have shrunk considerably from their volume when actively accumulating, due to de-watering.

Kalahroud Cave is dry today except in some of its lowest places. Figure 10 shows examples of the few evidences of the more rapid flow of phreatic waters or of local vadose entrenchment of highs in bedrock floors in The Maze that occurred during flood recession stages.

\section{The Corrosion Notch Chambers.}

The First and Second chambers are the largest voids of solutional origin in the cave (Fig. 4). Their enlargement is due primarily to the lateral extension of a principal corrosion notch at $2285 \mathrm{~m}$ asl, approximately the same elevation as the buried bedrock floor of the Kalahroud Gorge $~ 80 \mathrm{~m}$ further west. The morphology of the chambers is illustrated in Fig. 11. We consider these scenes to be "textbook examples" of the late stages of enlargement in a cavern that is being flooded sporadically at low filling rates. At highest water levels the chambers were filled, and solutional pockets were then etched into the ceilings by gravity-driven convection currents under near-static flow conditions. The relationships to the dipping beds are seen clearly in Fig. 11a and c. The flood waters drained down slowly to the externally-controlled $2285 \mathrm{~m}$ asl level, where they were retained for longer periods and the principal notch developed. Later lowering with lesser notching may be attributed to regional water table fall below the bedrock floor in the gorge, or to evaporation in the cave, or to a combination of these two processes.

\section{Clastic deposits in the cave.}

Kalahroud Cave contains quite a wide range of clastic and chemical sediments deposited by different mechanisms, making it a good site for sedimentary studies. The classification of White (2007) was used to categorize the clastic sediments, and standard particle size, texture and fabric methods applied to study them. Several different categories of chemical precipitates were noted. Most of them remain to be investigated in the future but an initial set of calcite raft samples was collected for U series dating.

The clastic sediments may be categorized as follows:

Allochthonous deposits, including entrance talus, infiltrates (in-washed soil), debris flows and mud masses (Fig. 12a-c). These are comparatively young sediments, derived from floods in the gorge and other 

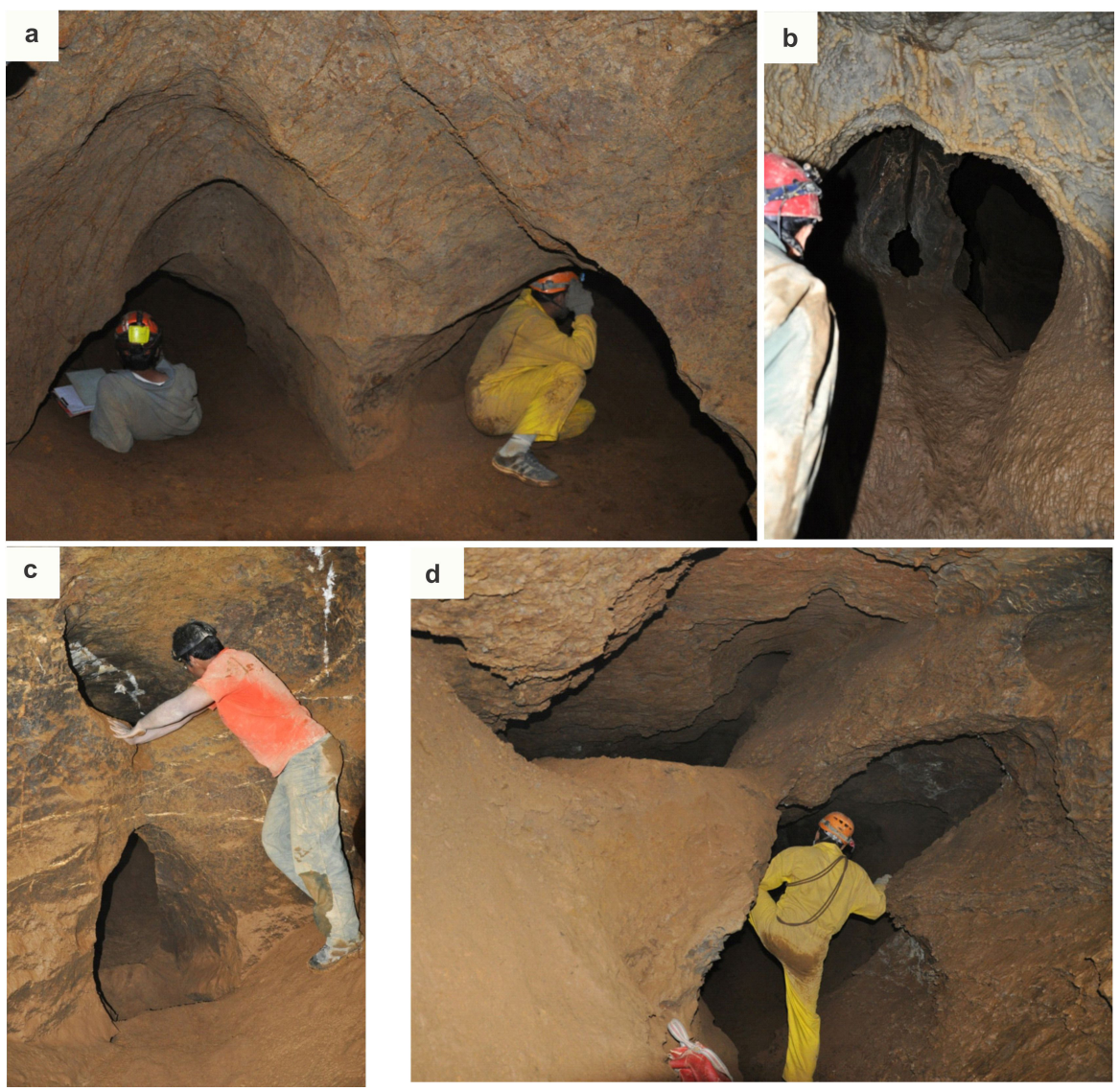

Fig. 7. Four examples of solutional partitions in The Maze.
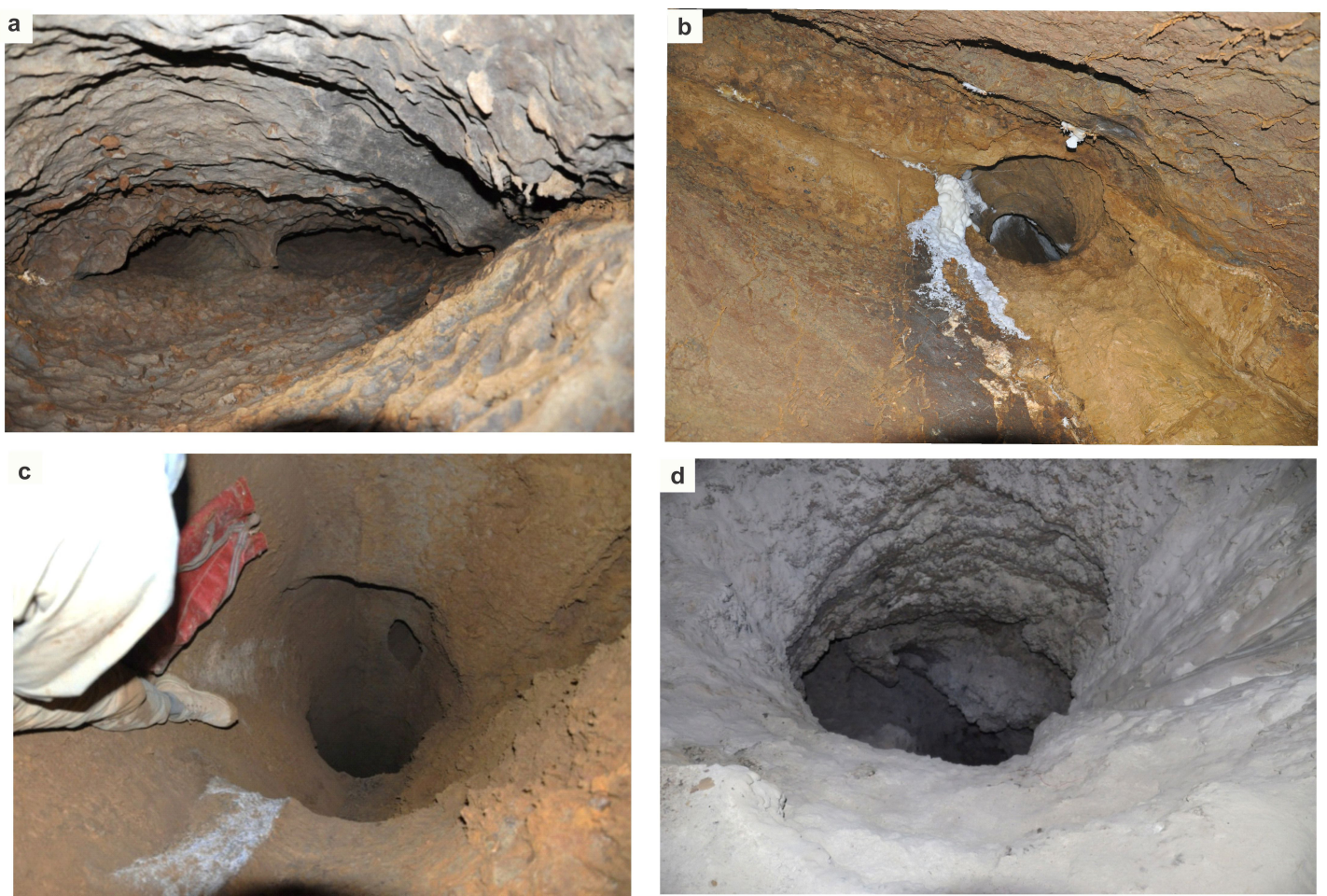

Fig. 8. a-b) Views looking vertically upwards into solution pockets in The Maze; the terminations are 5-10 m above the camera; c) A solutional shaft downwards in The Maze; d) Solutional shaft downwards with calcite raft debris, First Chamber.

events of the recent past. The finest-grained infiltrates form some mud mounds around the cave and small patches filling parts of solution pockets in the ceiling. An important feature of the sediments in the First and Second chambers with large notches is that they are not laminated and commonly have patchy calcite layers within them. Some contain white, hardened particles of small pebble size: microscope study determined that these were thin calcite rafts which probably were in the first stages of growth. These mixed clastic and precipitate sediments appear to have originated from river inflows in recent wet periods. On the walls they are covered by thin layers of dusty gray calcite precipitated from seepage from leaking joints, or from condensation waters in or close to the breakdown entrance ramp (Fig. 13d). 

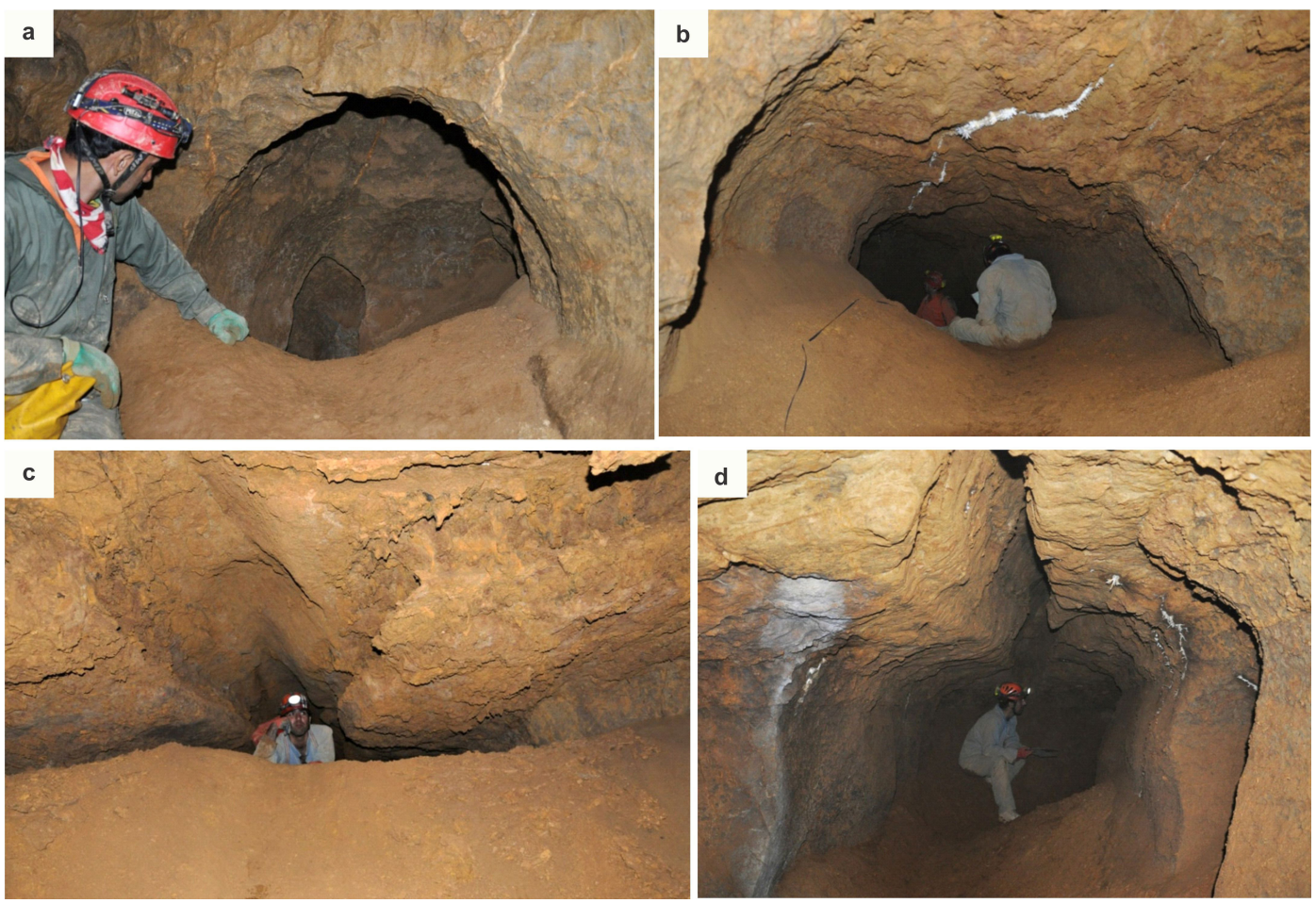

Fig. 9. a-c) Examples of the paragenetic effects (arched ceilings, corrosion notched walls) seen in The Maze; see the text for further details; d) Image showing that there has been tectonic displacement along the vertical joint since the passage was formed.
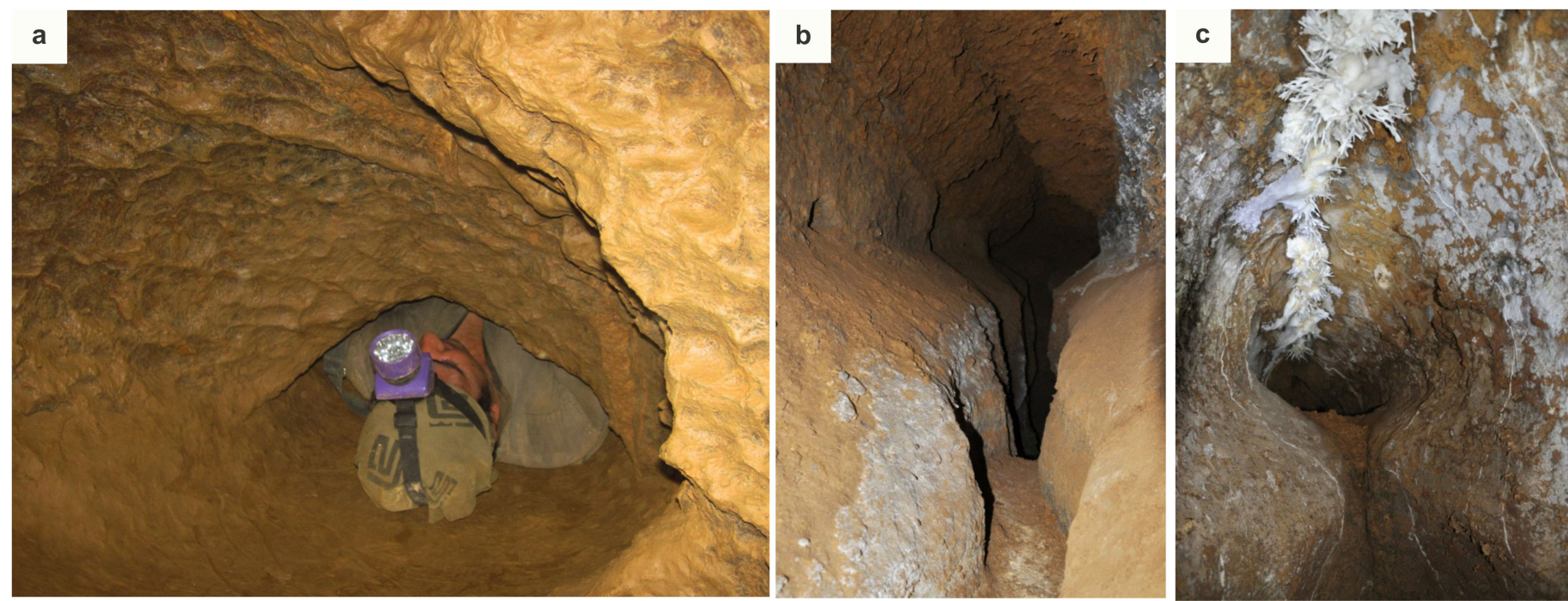

Fig. 10. Evidence of faster flow at venturi points (a), and of possible vadose entrenchment in the bedrock floors in The Maze (b-c). The scallops (a) are poorly developed, interpreted here as a combination of impure lithology and possible reversal of flow as floods surge and then subside.

Autochthonous sediments include the breakdown in the entrance area and paragenetic deposits of water-borne fines observed throughout The Maze. Samples were collected from the paragenetic clays and compared with others from intact mudstone beds within the host limestones. From the XRD analyses it was clear that the large volumes of mud in The Maze originate from weathering and erosion of mudstone layers in the host Taft Formation: there was no evidence of contributions from the underlying conglomerate and sandstone of the Sangestan Fm. (Fig. 12b-d).

\section{The speleothem precipitates}

The speleothems are either sub-aerial or pool deposits. A representative selection of the types is illustrated in Figs. 13-15. The sub-aerial deposits are quite widespread (e.g., as also seen in Figs. 6 and 10 in The Maze). They include small calcite stalactites, helictites, flowstones and popcorn, aragonite needles and frostwork. Thin veneers on the walls (e.g., Fig. 13d) possibly include some hydromagnesite and moonmilk but are dominated by precipitated skins of dust-laden calcite. Considered together, these are a suite of deposits typical of caves that are periodically wetted by seepage down joints but also experience dry, strongly evaporitic conditions, i.e., desert caves like many in Arizona, Nevada, New Mexico, etc.

The pool deposits are also varied. Figure $14 \mathrm{a}$ and $\mathrm{b}$ show examples of substantial pisolite and flowstone accumulations that imply deposition in long-lasting pondings. Figure $14 \mathrm{c}$ and $\mathrm{d}$ are nodular protrusions that possibly originated as shelfstones at the waterline, and later accreted sequences of silt, manganese and calcite layers as water levels fluctuated around them over comparatively long spans of time. They appear 
quite similar to sub-aqueous wall deposits in the extensive Jewel and Wind maze caves in South Dakota (Ford et al., 1993; Palmer \& Palmer, 2015) and will be investigated further in the future.

A final category of pool deposits are the large accumulations of calcite rafts and raft cones (cones of raft debris sunk beneath fixed drip points above a pool - Hill \& Forti, 1997) that are illustrated in Fig. 15. The principal deposits are in the First and Second chambers but there are lesser ones at and around the small pools in The Maze (see Fig. 4). Figure 15a shows the largest accumulation, which is in the First Chamber. Its waterline is at $2283 \mathrm{~m}$ asl, two meters below the principal corrosion notch. In the modern era it is known to fill to this level following floods.

In May 2012, a pit was dug where the piles of raft debris appeared to be deepest. It reached a silt and clay bottom at $-70 \mathrm{~cm}$ (Fig. 15d). Samples were taken from depths of 10,35 , and $70 \mathrm{~cm}$ and sent to the U-series dating laboratory at the Department of Earth Sciences, Oxford University (UK). The results are summarized in Table 1 . The samples have a low content of radiogenic ${ }^{234} \mathrm{U}$ and ${ }^{238} \mathrm{U}$ derived from solution of the bedrocks, and a comparatively high content of detrital (non-radiogenic) ${ }^{232} \mathrm{Th}$ that is probably from the dust particles about which initial calcite raft crystals precipitate. This is a common finding when calcites are dated in desert caves, as
Kaufmann (2002) found in a study of shelfstones in the Alisadr notch cave. ${ }^{232} \mathrm{Th}$ (and likely companion detrital ${ }^{230} \mathrm{Th}$ ) are contaminants that reduce the precision of the radio decay measure, ${ }^{234} \mathrm{U} \rightarrow{ }^{230} \mathrm{Th}$, requiring that an empirical correction be applied. In Table 1 it is seen that the uncorrected and corrected ages overlap at two standard deviations. The results may be considered decisive - the sampled raft deposit is of Holocene age, about 10,000 years old at the base and modern at the top, accumulating at an average rate of about seven $\mathrm{cm}$ per one thousand years.

\section{DISCUSSION}

\section{General morphology}

To summarize, Kalahroud Cave has three morphologically distinct parts (i) an entrance ramp of breakdown in the eastern wall of the Kalahroud River gorge, extending from $2323 \mathrm{~m}$ asl down to (ii) a pair of large corrosion notch chambers with a principal notch at $2285 \mathrm{~m}$ asl; (iii) behind the chambers and extending $\sim 500 \mathrm{~m}$ eastwards, a rectilinear, quasi-horizontal maze of generally narrower, joint-guided passages: The highest points in The Maze are northern, up-dip, ceilings at $\sim 2295 \mathrm{~m}$ and the lowest are shaft bottoms at $2263 \mathrm{~m}$ asl, so that the cave may be said to pass broadly through the middle of the $40+m$ thickness of the southeasterlydipping limestones of the Taft Formation.

Table 1. $U$ series ages of calcite rafts and cones in First Chamber, Kalahroud Cave.

\begin{tabular}{|c|c|c|c|c|c|c|c|c|c|c|c|}
\hline sample & {$\left[{ }^{\mathbf{2 3}} \mathbf{U}\right]$} & ${ }^{\mathbf{2 3 4}} \mathbf{U} /{ }^{\mathbf{2 3}} \mathbf{U}$ & $\mathbf{\pm}$ & ${ }^{\mathbf{2 3 0}} \mathbf{T h} /{ }^{\mathbf{2 3}} \mathbf{U}$ & $\mathbf{\pm}$ & ${ }^{\mathbf{2 3 0}} \mathbf{T h} /{ }^{\mathbf{2 3 2}} \mathbf{T h}$ & $\mathbf{\pm}$ & Uncorr. age & $\mathbf{\pm}$ & Corrected age & $\mathbf{\pm}$ \\
\hline & $\mathrm{ng} / \mathrm{g}$ & activity ratio & & activity ratio & & activity ratio & & yrs BP & yrs BP & yrs BP & yrs BP \\
\hline Y pcone & 368 & 2.22629 & 0.00908 & 0.01466 & 0.00364 & 1.96228 & 0.4872 & 659 & 180 & 366 & 247 \\
\hline Srcone & 314 & 2.21966 & 0.00899 & 0.04587 & 0.00364 & 3.25257 & 0.4872 & 2214 & 182 & 1660 & 339 \\
\hline FR pit base & 552 & 2.13386 & 0.00862 & 0.19401 & 0.00364 & 5.97008 & 0.4872 & 10263 & 67 & 8946 & 631 \\
\hline
\end{tabular}
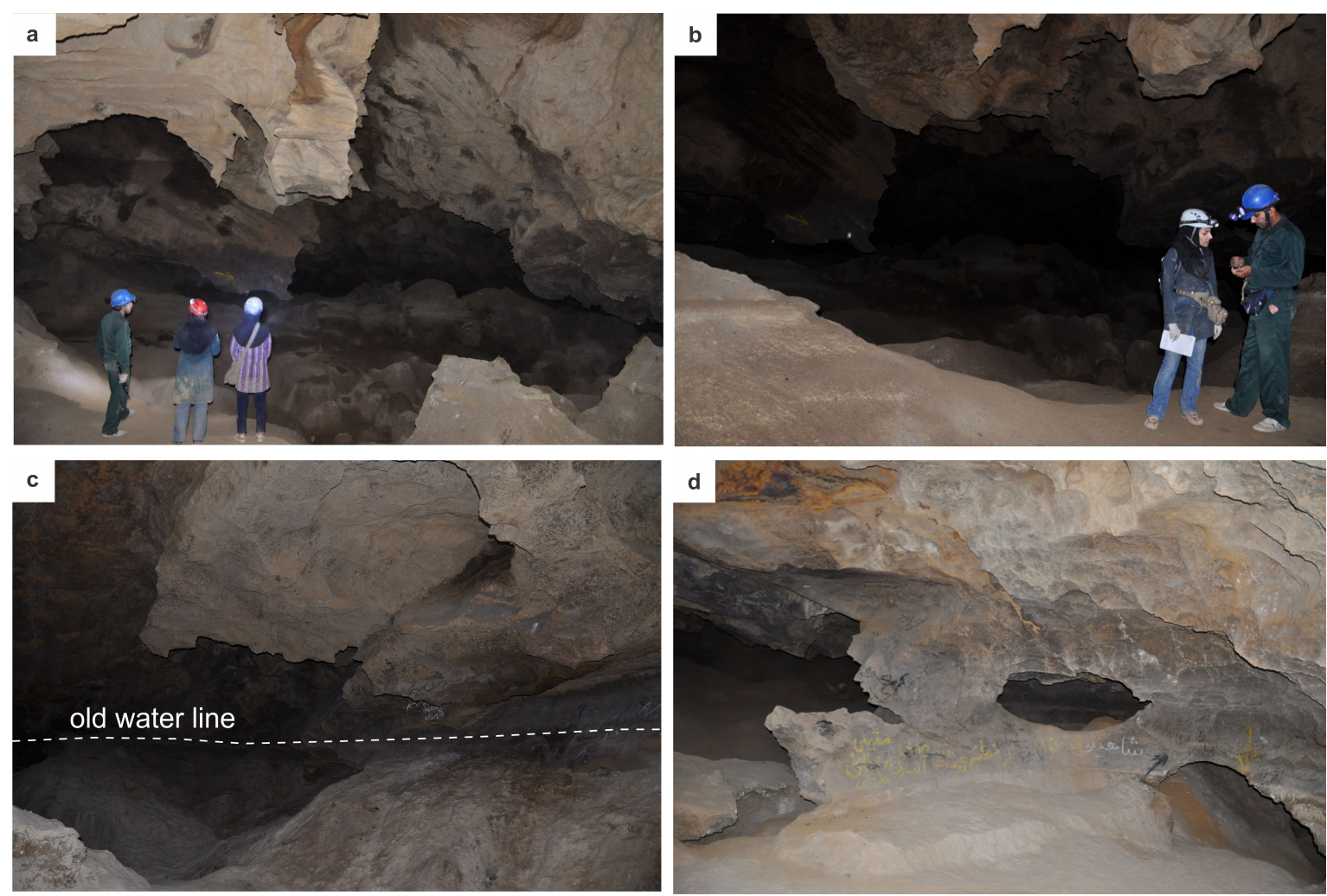

Fig. 11. Features of the main corrosion notch in the First and Second chambers. a-b) First Chamber, showing some past pool levels; c) Second Chamber, with the water level indicated; d) Partition morphology and a window formed at the water line, First Chamber. 

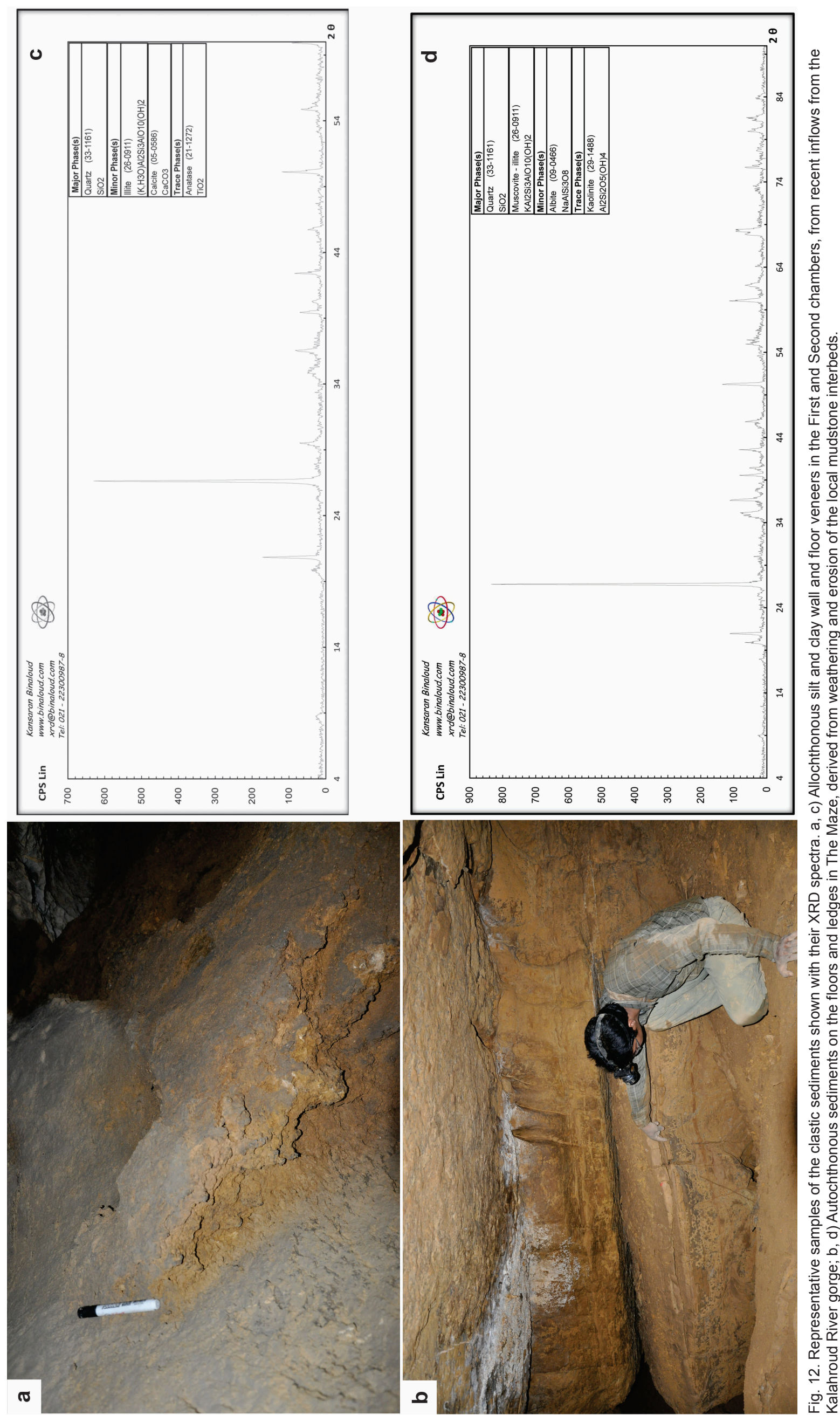

International Journal of Speleology, 45 (3), 243-257. Tampa, FL (USA) September 2016 

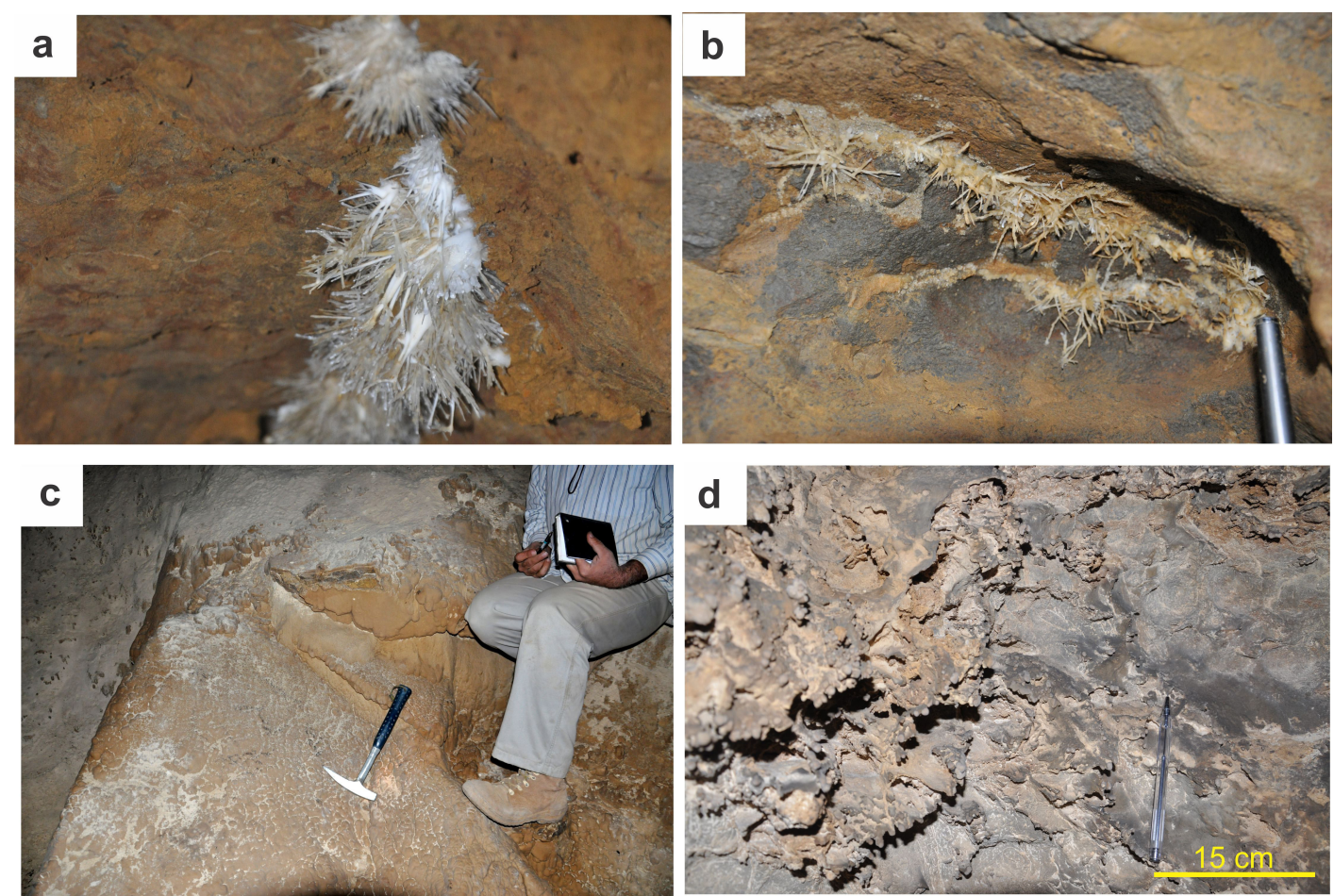

Fig. 13. Examples of the speleothems in Kalahroud Cave. a) Aragonite needles and frostwork; b) Calcite helictites; c) Calcite flowstone; d) Dust-laden calcite veneer on a wall.

\section{Origin of the Maze - by floods from the Kalahroud River gorge or by hypogene groundwater outflow into the gorge?}

The wide variety of characteristic solution features associated with slowly flowing phreatic waters that have been described above (ceiling height irregularities, deep solution pockets, bedrock pendants and partitions, etc), plus the paragenetic development involving fine-grained sediments derived entirely from mudstone beds within the local Taft Fm. limestone, are considered to be strong evidences that The Maze is of hypogene origin, rather than being a river bank floodwater maze formed in mixed vadose-phreatic conditions where much more rapid rates of flow would be expected. As far as the cave is known today, the sources of the water appear to be the basal shafts shown in Figures $3 \mathrm{~b}$ and 4 that were created by rising groundwaters (phreatic lifts), plus others possibly concealed by the clastic sediments, and perhaps other inputs further to the east or down the dip that may be discovered in future exploration. Basal lifting shafts are prominent features in perhaps the majority of the hypogene maze caves being described in the literature today. It is quite possible that much of basal recharge into Kalahroud Cave was from water rising through the underlying, insoluble but well-fractured, sandstones and conglomerates of the Sangestan $\mathrm{Fm}$, rather than laterally through the basal few meters of the Taft limestone that lie beneath the bottoms of the shafts.

However, The Maze is constrained within a narrow vertical range (2295 to $2263-\mathrm{m}$ asl) that is strikingly discordant to the stratal dip when viewed at the scale of a long section (Fig. 3b). This must be due to the entrenchment of the Kalahroud Gorge through the cover strata at $\sim 2350-2450 \mathrm{~m}$ asl. This permitted groundwater flow through the Taft Fm aquifer, with discharge in the earliest springs at around $2300 \mathrm{~m}$.
With continued entrenchment of the gorge, the upper parts of The Maze drained first, then the system stabilized at the main notch level $(2285 \mathrm{~m}$ asl) when the gorge became shallowly aggraded. The weaker notches seen in The Maze are also at or within one meter of $2285 \mathrm{~m}$ asl.

\section{Why is the main corrosion notch limited to the First and Second chambers?}

As noted, the main corrosion notch is found at approximately $2285 \mathrm{~m}$ asl, which is also the elevation of the bedrock channel floor in the Kalahroud River gorge, a mere 80-100 m west of the First Chamber. The notch is continuous and deep in the two chambers (Fig. 11). Further back in The Maze there are four examples of merely local corrosion notching, also at $\sim 2285 \mathrm{~m}$ asl (Fig. 4).

The limitation of deep main notching to the downstream end of the cave differs sharply from the pattern seen in Alisadr Cave (Hamedan), which Ford and Williams (2007) have cited as an ideal example of corrosion notch cave development in dry regions. At Ghar Alisadr, a high but narrow ridge of tightly folded and steeply dipping Jurassic limestones and schists is surrounded by modern desert fans and alluvium. A perennial spring with very high $\mathrm{P}_{\mathrm{CO}_{2}}$ rises through the alluvium a short distance away. Kaufman (2002) proposed that the cave is of hypogene, enriched aqueous $\mathrm{CO}_{2}$ origin, with a deep bedding plane- and joint-guided solutional maze of passages that was discharged over a natural bedrock dam at the outlet. Deep lateral notching at the level of the dam extends throughout the full $(\sim 400 \mathrm{~m})$ extent of the tourist cave. The hypogene waters may also have been refreshed by recharge entering overhead and at many different points around the perimeter of the ridge. The notching induced local collapse that left some large breakdown chambers above the waterline. 

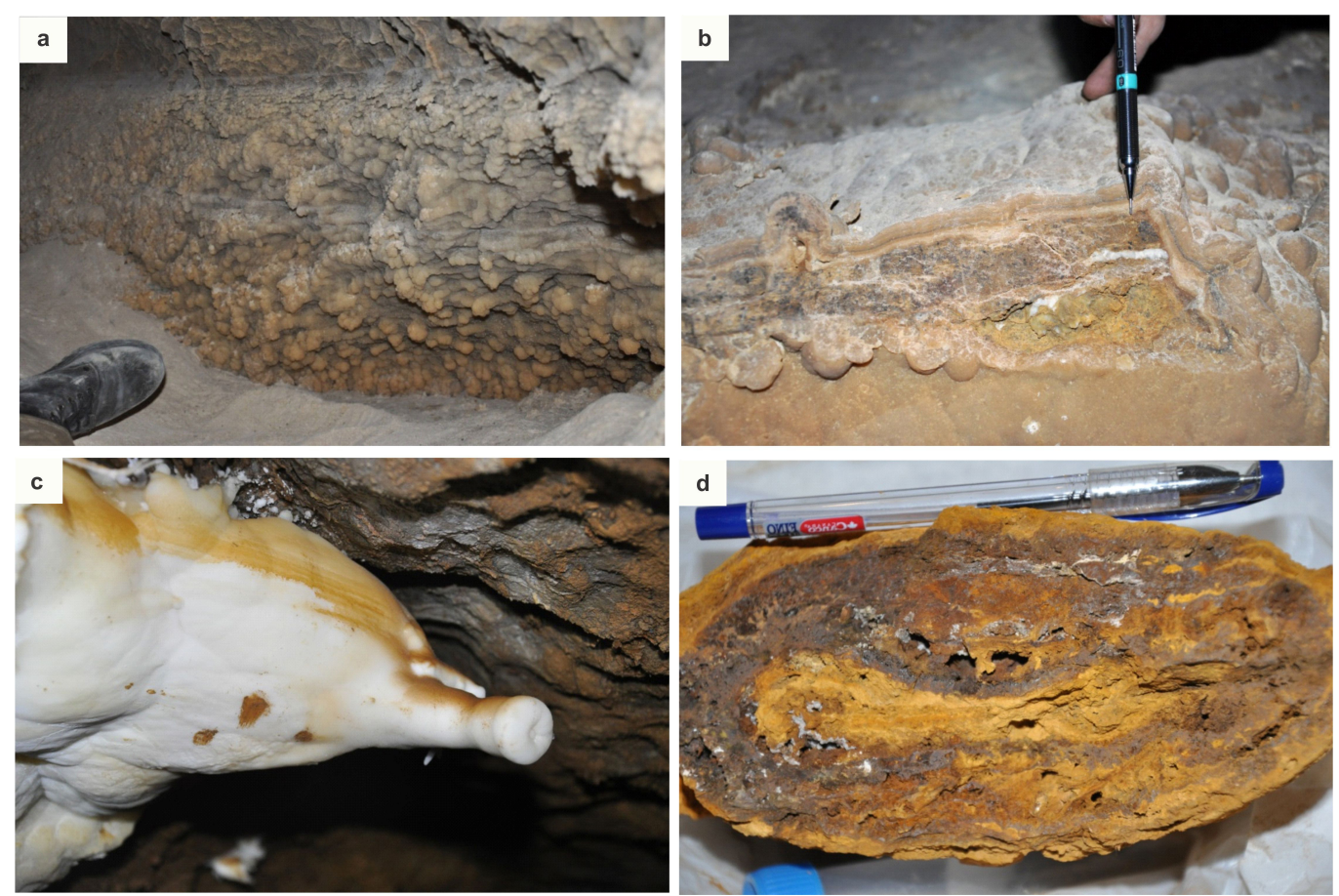

Fig. 14. a-b) Pisolite and nodular precipitates in the First and Second chambers, probably sub-aqueous; c) A shelfstone protrusion of calcite in The Maze; the dust veneer is from caving activity; d) Section through a shelfstone projection of calcite- and (manganese?)-cemented silts.

These contain conventional dripstone speleothems. Many sections of the Ghar Alisadr notch are now filled with multiple generations of calcite shelfstones that extend over a height of $\sim 1.5 \mathrm{~m}$, suggesting that the waterline fluctuated within this narrow range for a significant period of time. Erosion of the natural dam then lowered the waterline one meter or more below the notch, where it is now stabilized artificially. The shelfstones are Holocene in age (Kaufman, 2002)

By analogy, in Kalahroud Cave deep corrosion notching was limited to the First and Second chambers (and probably to points downstream of them now inaccessible because of the collapse) because only there could the chemically saturated hypogene waters flowing from the inner cave be refreshed by lateral and overhead recharge from the adjoining gorge. These latter intruding waters were chemically aggressive in their own right and could also give a mixing corrosion boost to the hypogene flow. The creation of the breakdown entrance ramp in the cave is best attributed to this combination of aggressive intruding water and deep corrosion notching that undermined the local bedrock.

\section{Interpreting the precipitates below the main notch}

In distinct contrast to the situation at Alisadr Cave, however, no shelfstone has been deposited in the main notch in the First and Second chambers of Kalahroud Cave. Instead, below the notch there are (i) widespread deposits of older subaqueous layered or nodular calcites (some with probable Mn-rich bands), plus a few small subaerial stalagmites and flowstones (Figs. 13c, 14a,b): where natural breakage has exposed examples of the subaqueous forms in cross-section they do not appear to contain any calcite raft material. Overlying many of these deposits and burying them in places are (ii) a final stage of calcite raft formation and deposition, including construction of the tower cones
(Fig. 15). Many cones terminate at one of two pond levels, the higher of which is two meters below the main notch and $\sim 0.50$ meters below what is believed to be the modern maximum flood level.

Our provisional interpretation is that the older subaqueous calcites were precipitated either together with the development of the corrosion notch or immediately after it. During a flood in which autogenic waters from The Maze mixed with allogenic waters from the gorge, the two chambers were first filled to $\sim 2290 \mathrm{~m}$ asl, allowing some convectional solution in the ceilings. They drained slowly until arrested by an external dam at $2285 \mathrm{~m}$ asl: the waters were still acidic, the main notch was created at this waterline, suspended sediments settled out beneath it and the first calcites may have begun to precipitate from locally denser, saturated solutions descending from it. Following this, a combination of very slow seepage loss below the level of the dam and evaporative loss into the two chambers would have lowered the waterline further and accelerated the rate of calcite deposition - until the next flood came along to repeat the cycle. Our future research will include $U$ series dating of representative samples of the Stage (i) subaqueous calcites*.

The dated calcite rafts of Stage (ii) are from two tower cones and the bottom of the sample pit dug in the floor of the First chamber, where it was believed that their accumulation was deepest. It is possible that there are deeper accumulations that might yield slightly greater ages elsewhere in the two chambers. In the sample pit it is seen that the rafts rest on a base of Stage (i) clays and that there are no further clay deposits higher up within them (Fig. 15e). The dates indicate firmly that the raft accumulation began there between 9,000 and 10,000 years ago and that it continues episodically today.

The switch from Stage (i) clay and subaqueous calcite deposition to Stage (ii) no clay and the 

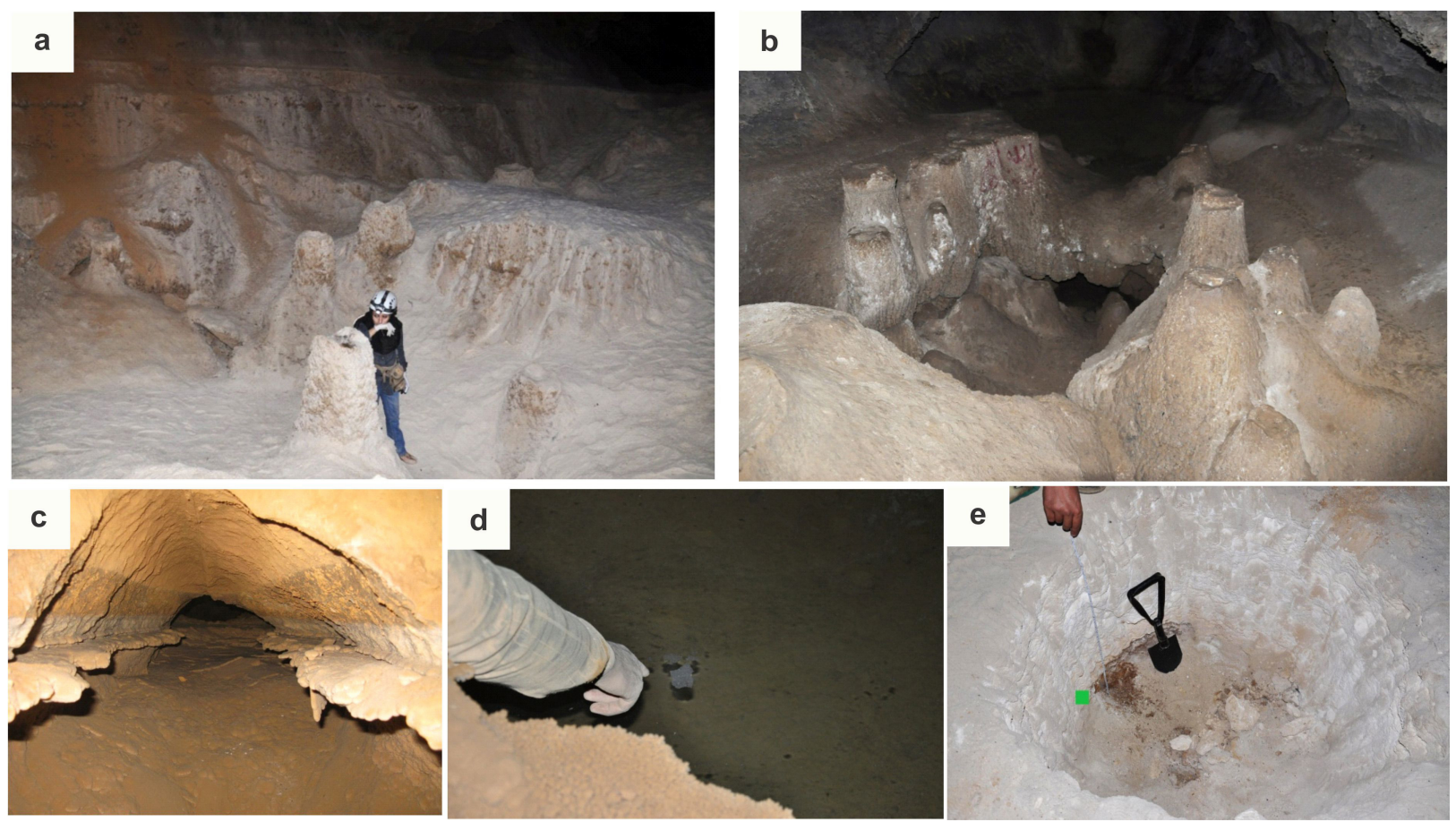

Fig. 15. Calcite rafts and cones in Kalahroud Cave. a) Raft cones and pool deposits in the Second Chamber; b) Successive lower and upper generations of raft cones on the approach to The Maze. Further into The Maze; c) Waterlines, shelfstones and raft debris, and (d) A modern raft on a residual pool; e) The $70 \mathrm{~cm}$ deep sampling pit excavated in the raft debris on the pool floor in First Chamber.

predominance of waterline raft formation, was abrupt. We believe that this may have been caused primarily by the bedrock collapse event beneath the entrance. This greatly reduced or entirely eliminated intrusion by clay-laden waters from the Kalahroud River gorge. Now there was only the a-periodic inflow of autogenic (hypogene) water from the local lifting shafts, plus minor contributions from overhead seepage through the marl cover beds. An alternative explanation is that because Holocene warming increased the air temperature in the cave (our estimate is by five degrees $\mathrm{C}$ or more) the evaporation rate increased sufficiently for raft formation to overwhelm the other processes. This possibility does not account for the apparently complete cessation of clay deposition in the pools in the two chambers, however, and thus is considered to be a secondary factor at most.

As noted, in the $70 \mathrm{~cm}$ sampling pit the rafts accumulated at a mean rate of about $7.8 \mathrm{~cm} / 1000$ years. However, the individual floods and the formation of rafts on their receding waters are a-periodic events, so that mean rates are much generalized representations of what has taken place recently in the cave. An alternative approach is to speculate on the likely number of raft-forming floods required to build the $70 \mathrm{~cm}$ accumulation over the last 9000 years or so. The range of individual calcite raft thicknesses is $\sim 1-4 \mathrm{~mm}$ in our experience. Allowing for $30 \%$ porosity in the $70 \mathrm{~cm}$ accumulation this yields between $\sim 500$ (maximum) and $\sim 120$ (minimum) events, or one every 18 to 72 years on average. This is broadly in accordance with the local report that there has been only one flood through the Kalahroud Gorge during the past 25 years or more. This is crude estimation but, it is hoped, will give speleologists some appreciation of the frequency of formative events in arid regions.

\section{CONCLUSIONS}

Kalahroud Cave is a relatively extensive, phreatic/ paraphreatic, maze cave in a semi-arid to arid mountainous region near the city of Isfahan. It is formed in Cretaceous limestones and calcareous mudstones that overly siliceous conglomerates and sandstone and are capped by weaker limestone marls. Surface a-periodic stream entrenchment along the strike of the SE-dipping rocks created an east-west cuesta. A larger torrential stream from the north, 'Kalahroud River', entrenched a shallow gorge across the cuesta, permitting development of strike-oriented groundwater flow in the limestones, with discharge into the gorge. A joint-guided rectilinear maze of solutional passages developed, fed by hypogene (phreatic lifting) shafts from below. The maze is quasi-horizontal, with a vertical extent of $\sim 30 \mathrm{~m}$ that is slightly discordant to the stratal dip. Continued entrenchment of the gorge began to drain the highest parts of the maze but was halted by a stillstand in the channel erosion. In the downstream sector of the cave, mixture of phreatic waters from the maze with occasional floodwaters from the river created deep lateral corrosion notching at the stillstand level. This was succeeded by channel aggradation at the surface and, probably, the beginning of shelfstone and sub-aqueous calcite deposition below the notch. Undermined by the notching, part of the gorge wall collapsed into the downstream end of the cave. Since that event, formation and deposition of calcite rafts has predominated in the a-periodic pondings, the earliest being about 10,000 years BP in age. Raft waterlines have been one-two meters or more below the level of the main corrosion notch, indicating that the karst ground waters are now leaking away downstream of the gorge, presumably into the alluvium that helps sustain the qanats of the village of Kalahroud. 
The relationships of gorge and cave enlargement, stillstand and aggradation in the river channel, thick shelfstone and thin raft formation in the cave, to the tectonic and climatic histories of the region will be investigated further in future work.

\section{ACKNOWLEDGEMENTS}

Lotfizadeh. S, Navaie. O, Jamali. H, Sabokkhiz. F. Sohrabi. A, and other cavers who accompanied us, are acknowledged for their help when visiting Kalahroud Cave and collecting samples there. S. Lotfizadeh is cordially thanked for his thorough and detailed mapping of the cave. We also wish to express our appreciation of the excellent thin sections of sensitive and brittle samples prepared by Farhad Ilback. A. Arghavani, Head of the Regional Meteorology Department is thanked for providing detailed rainfall data. Three anonymous referees provided helpful comments on the manuscript.

\section{REFERENCES}

Audra P. \& Palmer A.N., 2015 - Research frontiers in speleogenesis. Dominant processes, hydrogeological conditions and resulting cave patterns. Acta Carsologica, 44 (3): 315-348. http://dx.doi.org/10.3986/ac.v44i3.1960 Bahadorinia S., Hejazi H., Nadimi A. \& Ford D.C., 2013 - An Introduction to Kalahroud Cave, North of Isfahan, Iran. In Filippi M., Bosák P. (Eds). Proceedings of the $16^{\text {th }}$ International Congress of Speleology, Praha, Czech Speleological Society, 3: 499.

Bella P. \& Bosak P., 2012 - Speleogenesis along deep regional faults by ascending waters: Case studies from Slovakia and Czech Republic. Acta Carsologica, 42 (2-3): 169-192. http://dx.doi.org/10.3986/ac.v41i2-3.556

Berberian F., Muir I.D., Pankhurst R.J. \& Berberian M., 1982 - Late Cretaceous and early Miocene Andean type plutonic activity in northern Makran and central Iran. Journal of the Geological Society of London, 139: 605-614. http://dx.doi.org/10.1144/gsjgs.139.5.0605

Bosak P., Bruthans J. \& Filippi M., 1999 - Karst and Caves in the Salt Diapirs, SE Zagros Mts., Iran. Acta Carsologica, 28 (2): 41-75.

Bruthans J., Filippi M., Geršl M., Zare M., Melková J., Pazdur A. \& Bosák P., 2006a - Holocene marine terraces on two salt diapirs in Persian Gulf (Iran): age, depositional history and uplift rates. Journal of Quaternary Science, 21 (8): 843-857.

http://dx.doi.org/10.1002/jqs.1007

Bruthans J., Filippi M., Zare M., Asadi N. \& Vilhelm Z., $2006 b$ - 3N Cave $(6580 \mathrm{~m})$ : Longest salt cave in the world. The NSS News, 64 (9): 10-18.

Calaforra J.M. \& De Waele J. 2011 - New peculiar cave ceiling forms from Carlsbad Caverns (New Mexico, USA): the zenithal ceiling tube-holes. Geomorphology, 134 (1): 43-48.

http://dx.doi.org/10.1016/j.geomorph.2011.02.032

Ford D.C., Palmer A.N., Palmer M.V., Dreybrodt W., Lundberg J. \& Schwarcz H.P., 1993 - Uranium series dating of the draining of an aquifer: the example of Wind Cave, Black Hills, South Dakota. Bulletin, Geological Society of America, 105: 241-250.

http://dx.doi.org/10.1130/0016-7606(1993)105 $<0241$ :USDOTD $>2.3 . \mathrm{CO} ; 2$

Ford D.C. \& Williams P.W. 2007 - Karst hydrogeology and geomorphology. Wiley, Chichester, $506 \mathrm{p}$.

http://dx.doi.org/10.1002/9781118684986
Hejazi S.H., Jamali H. \& Molaei M., 2015 - Cave speleogenesis East of Golpaygan, Iran. Proceedings $23^{\text {rd }}$ International Karstological School "Classical Karst", Postojna, Slovenia, 120-121.

Hill C.A. \& Forti P., 1997 - Cave minerals of the world. National Speleological Society, Huntsville, 463 p.

ISEI, 2008 - Records of the ISEI Expedition 2008 (Union Internationale de Spéléologie).

Jennings J.N., 1985 - Karst geomorphology. Basil Blackwell, Oxford, 293 p.

Judson D., 1973 - The discovery and exploration of Ghar Parau (Iran). Transactions, Cave Research Group of Great Britain 15 (1): 19-26.

Kaufmann G., 2002 - Ghar Alisadr, Hamadan, Iran: first results on dating calcite shelfstones. Cave and Karst Science, 29 (3): 129-133.

Klimchouk A.B., 2000 - Speleogenesis under deep-seated and confined settings. In: Klimchouk A., Ford D.C., Palmer A.N. \& Dreybrodt W. (Eds.), Speleogenesis: Evolution of karst aquifers. National Speleological Society, Huntsville: 244-260.

Klimchouk A.B., 2007 - Hypogene speleogenesis: Hydrogeological and morphogenetic perspective. Special Paper No. 1, National Cave and Karst Research Institute, Carlsbad, New Mexico: 106 p.

Palmer A.N. \& Palmer M.V., 2015 - Geologic history of the Black Hills Caves, South Dakota. In: Feinberg J., Gao Y., Alexander E.C. Jr (Eds.) Caves and Karst across Time. Geological Society of America, Special Paper 516: 87-101. http://dx.doi.org/10.1130/2015.2516(07)

Pasini G., 1973 - Sull'importanza speleogenetica dell'erosione antigravitativa'. Le Grotte D'Italia 4a (4): 297-308.

Pasini G., 2012 - Speleogenesis of the "Buco dei Vinchi" inactive swallow hole (Monte Croara karst sub-area, Bologna, Italy), an outstanding example of antigravitative erosion (or "paragenesis") in selenitic gypsum. An outline of the "post-antigravitative erosion". Acta Carsologica, 41 (1): 15-43.

http://dx.doi.org/10.3986/ac.v41i1.45

Raeisi E. \& Kowsar N., 1997 - Development of Shapour Cave, Southern Iran. Cave and Karst Science, 24 (1): 27-34.

Raeisi E. \& Laumanns M., 2003 - Iran cave directory. Berliner Höhlenkundliche Berichte, 10: 101 p.

Raeisi E., Ghazi S. \& Laumanns M., 2012 - Iran cave directory. Berliner Höhlenkundliche Berichte, 10: 315 p.

Rezaei M. \& Nakhaei M., 2008 - Speleogenesis of Katale-khour Cave, Zanjan Province. Faslname ye Zaminshenasi ye Iran, 2 (6): 11-19 (in Farsi).

Javanshad A., 1995 - Caves and cavers. Ali Javanshad, Tehran, 286 p. (in Farsi).

Renault H.P., 1967 - Contribution à l'étude des actions méchaniques et sédimentologiques dans la spéléogenèse. $3^{e}$ partie: Les facteurs sédimentologiques. Annales de Spéléologie, 22: 5-21; 209-267.

Renault H.P., 1968 - Contribution à l'étude des actions méchaniques et sédimentologiques dans la spéléogenèse. Annales de Spéléologie, 23: 259-307; 529-596.

Renault H.P., 1969 - Contribution à l'étude des actions méchaniques et sédimentologiques dans la spéléogenèse. Annales de Spéléologie, 24 (2): 317-337.

Sabokkhiz F., Hejazi S. \& Moghadasin M., 2012-Analysis of geotourism of Khas e Tarash Cave by the Pralongn method. Geography and Environmental Planning, 23 (2): 69-86.

Temovski M., Audra P., Mihevc A., Spangenberg J.E., Polyak V.J., McIntosh W. \& Bigot J.Y., 2013 - Hypogenic origin of Provalata Cave, Republic of Macedonia: a distinct case of successive thermal carbonic and sulfuric acid speleogenesis. International Journal of Speleology, 42 (3): 235-246.

http://dx.doi.org/10.5038/1827-806X.42.3.7 
White W.B., 2007 - Cave sediments and paleoclimate. Journal of Cave and Karst Studies, 69 (1): 76-93.
Zahedi M., 2005 - Sheet 6356 Geological map of Tarq. Geological Survey of Iran. Scale 1:100.000. 